\title{
Restoration of the interior of the Summer Lubomirski Palace in Rzeszow
}

\author{
Krystyna Wróbel $^{*}$, and Wiesław Kubiszyn \\ Faculty of Civil and Environmental Engineering and Architecture, Rzeszow University \\ of Technology, Al. Powstańców Warszawy 12, 35-959 Rzeszów, Poland,
}

\begin{abstract}
The Lubomirski Summer Palace is one of the most valuable not sacred monuments of Rzeszow architecture. It was erected in the late baroque style at the end of the 17th century by Hieronim Augustyn Lubomirski as part of a large garden complex around the castle. Times of his glory fall in the mid-18th century. At that time, palace with the surrounding park was extended by Jerzy Ignacy Lubomirski and became a residence willingly visited for recreational purposes. The last private owners of the Palace were Nieć family who sold it to the Regional Medical Chamber in Rzeszów. Since 2014, the palace and its surroundings have been renovated for the seat of the Chamber. The subject of this article is a detailed presentation of the scope and method of the palace interior renovation. This renovation was carried out between 2014 and 2016 on the basis of previously prepared architectural building documentation and detailed renovation technology developed by the author of the article (adapted to the technical condition of the object). The article describes in detail the technical condition of the building before renovation, the scope of renovation works, problems encountered and the final effect - restored interiors of the building with few historic details of their décor.
\end{abstract}

\section{Historycal view}

The Lubomirski Summer Palace is one of the most valuable not sacred monuments of Rzeszow architecture. It was erected at the end of the 17th century by Hieronim Augustyn Lubomirski based on the design of Tylman van Gameren in the late baroque style with elements of rococo $[1,2]$. The palace was built on the site of the former winery of Mikołaj Spytek Ligęza. It was part of a large garden complex around the Lubomirski Castle. Times of his glory fall in the mid-18th century. At that time, palace with the surrounding park was extended by Jerzy Ignacy Lubomirski and became a residence willingly visited for recreational purposes.

Soon after, the third floor was added to the central part of the building. At the end of the eighteenth century the palace and the surrounding garden began to fall into ruin. In 1798 the palace and the garden were sold to the Kosthein family by Franciszek - another owner from the Lubomirski's family. The rest of the garden with the castle was sold to the Austrian government in 1819. The palace was rebuilt after a fire, which according to

\footnotetext{
${ }^{*}$ Corresponding author: wrobel@prz.edu.pl
} 
various sources was most likely in 1906. The Kosthein family sold the Palace to the Nieć family in 1908. The palace was rebuilt and in 1938 the owners established a field hospital there. In 1959, the complex was entered into the register of monuments [3]. In the 1970s, the last private owners of the palace, the Niec family, were expropriated for symbolic compensation. After the renovation carried out in the early 1980s, the Palace was put into use by various state institutions. In 2012, after years of fighting, the Nieć family recovered the object and then sold it in 2013 to the Regional Medical Chamber in Rzeszów.

\section{General description of the object}

The palace was erected as a brick made of solid brick, built partly on stone foundations and partly on solid bricks. The building is $\mathrm{H}$-shaped in plan view, symmetric with respect to two perpendicular axes, completely basement.

In the middle part the building is three-storey. Side wings are two-storey with the third floor in the mansard roof with dormer windows. The middle section is covered with a saddle-type gable roof. Roofing, all flashings, gutters and downpipes are made of copper sheet. The basic dimensions of the building and the location on the map are shown in Fig. No. 1. The general view of the west façade is shown in Fig. No. 2.

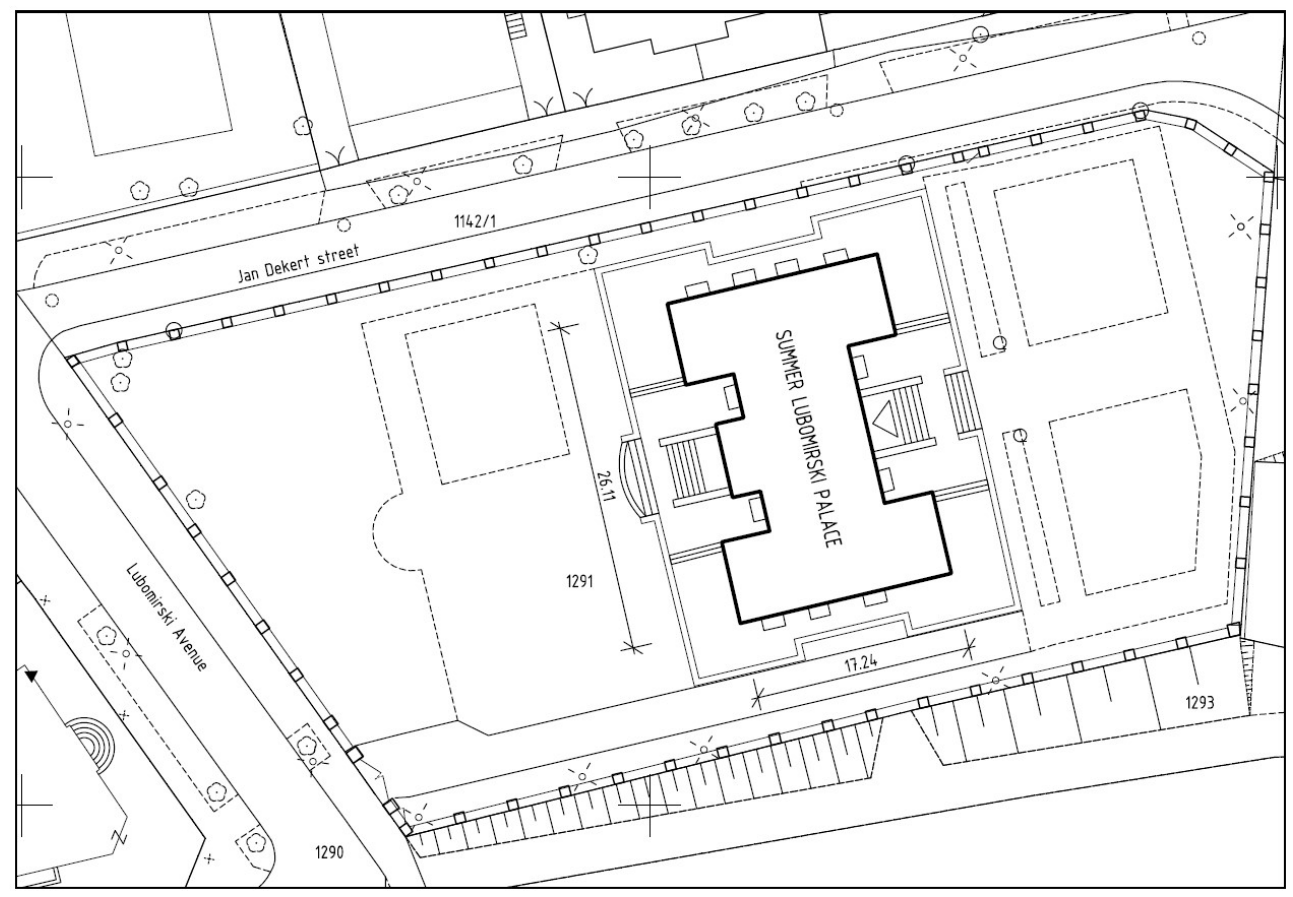

Fig. 1. Location of the Palace in the area

\section{The overall scope of the palace renovation and its surroundings}

Since 2014, the palace and its surroundings have been renovated for the seat of the Medical Chamber. In the first place the interiors were renovated, then the fence, facades and the nearest surroundings - stairs and terraces. Building the internal road and car park has been planned for the next period. The final stage will be a garden in the western, front part of the 
estate. It will be restored according to the original Widemann's assumptions from the 18th century. The subject of this paper is a detailed presentation of the scope and method of renovation of palace interiors. This renovation was carried out in the years 2014-2016, based on the previously prepared architectural and structural documentation [4] and a detailed renovation technology developed by the authors of this article (adapted to the real technical condition of the object) $[5,6]$.

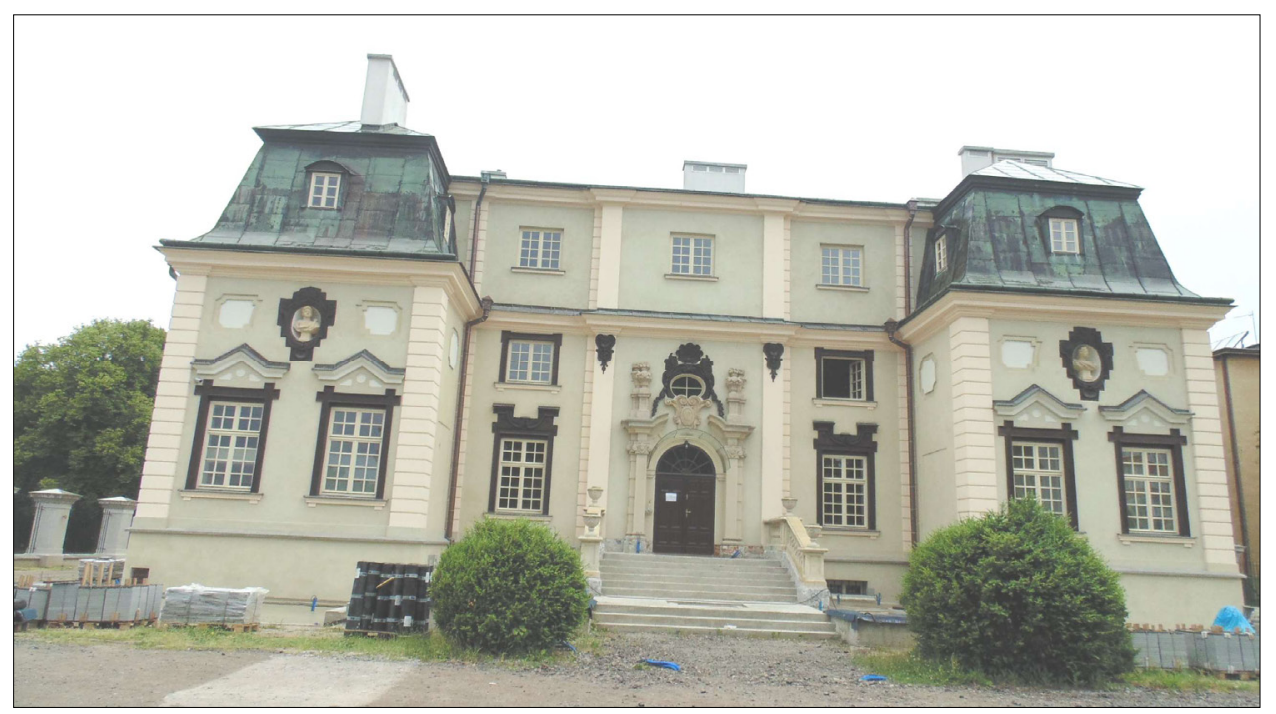

Fig. 2. General view of the west façade

\section{A detailed description of interior renovation and related problems}

The interior renovation started at the end of January 2014 with the removal of all technically worn finishing elements that do not have a historical value. Then it turned out that the previous renovation was carried out in a very superficial way. All defects of the walls, including those in the basement, were masked with plasterboard. The issue of the most vital importance for the durability of the object was omitted, which is a damp insulation of the underground part of the building and external basements (located outside the outline of the aboveground part) (Fig. 3 - 8). Rainwater and snowmelt reached the basement from concrete window casings located below the ground level, through the leakage of their walls and the windows themselves which were in poor technical condition. 


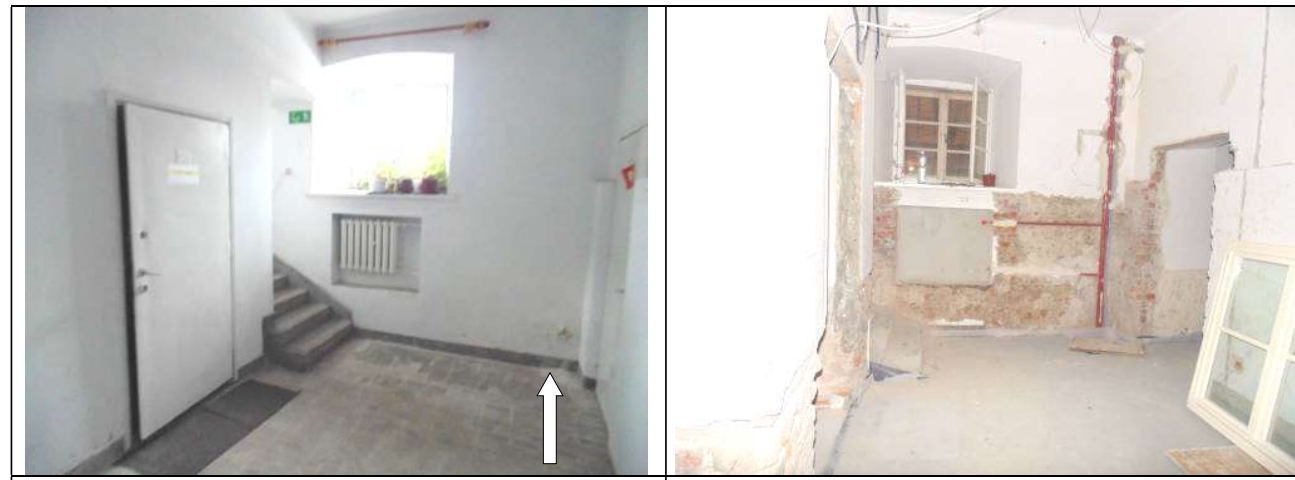

Fig. 3. Moistening of the wall - basements, level "-1" near the stairs to the ground floor

Fig. 4. Like in the previous picture - walls after removal of damp plaster

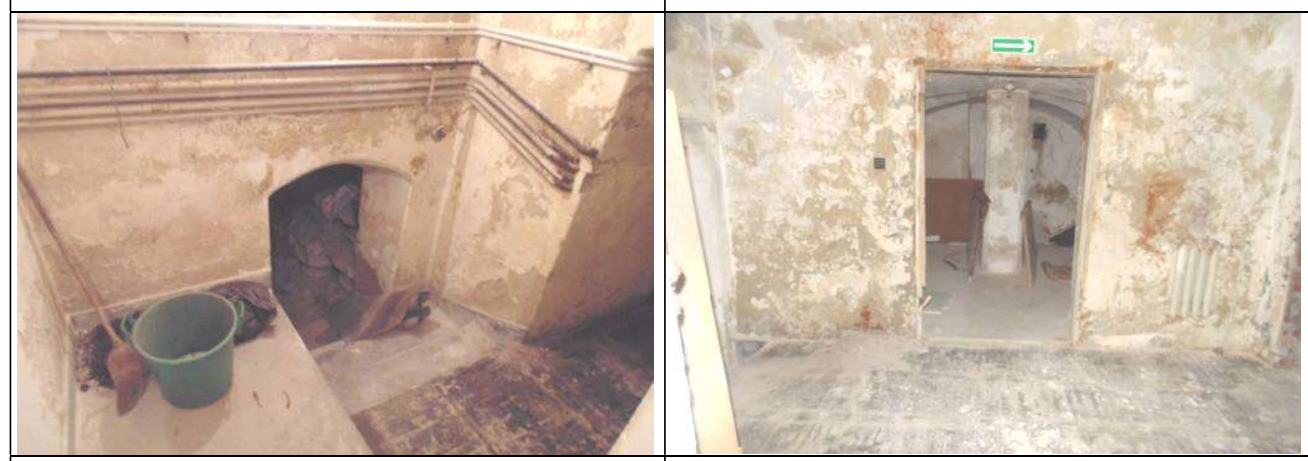

Fig. 5. Wall moisturization and corrosion of the installation at the entrance to the eastern outer besement

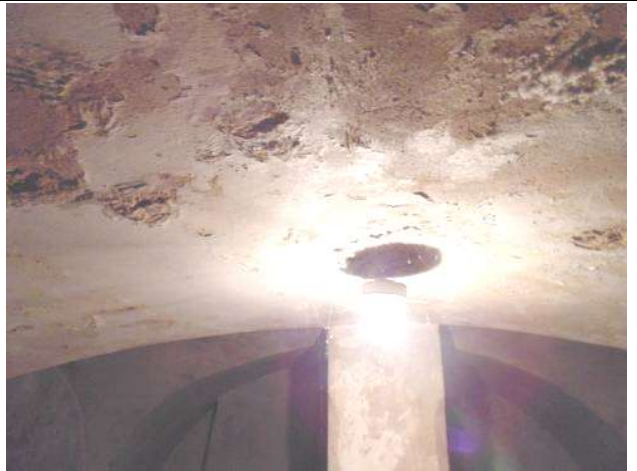

Fig. 6. Outer southern basement, level "-2" biological corrosion of the entire enclosure

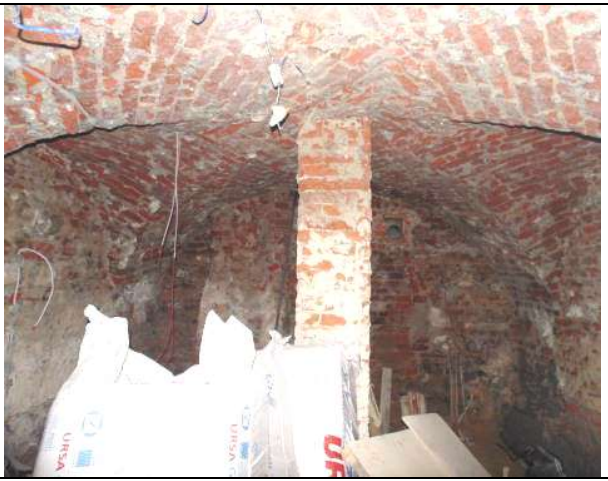

Fig. 7. Moisture of the ceiling and salt Fig. 8. View of a completely damped floor from efflorescence around the column visible in Fig. 6 Fig. 8 - after plastering 


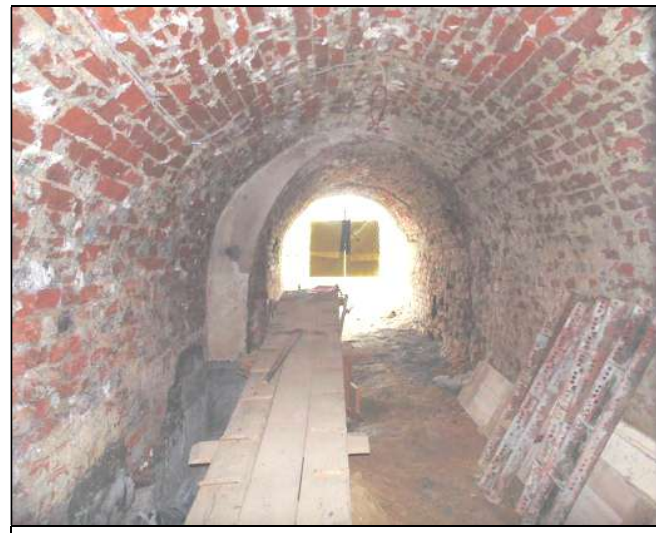

Fig. 9. Exit towards the fountain - completely damp vault and walls after plastering

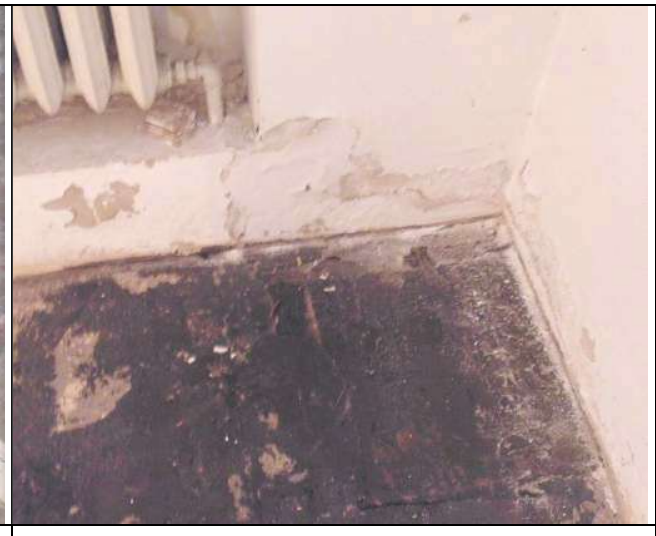

Fig. 10. Corrosion damage in the north-east corner of basement.

Plasters from entire damp surfaces were removed with a flange min. $80 \mathrm{~cm}$ above (Figures 4, 8, 9). Large damages in the pedestal and underground parts of the building were also caused by leaky and incomplete drainage pipes (Figures 11-13). Damage shown in Fig. 11 and 12 is the result of the above-mentioned disadvantages. Over 30 years old internal installations were dismantled. The ventilation chimneys of the underground part of building have been opened. Basement prepared in this way was left to self-dry for about a year and a half. Supplementation of too shallowly placed foundations from the inner side were made. In the summer, with favorable weather conditions, damp insulation and supplementation of too shallow foundations from the outside were made.

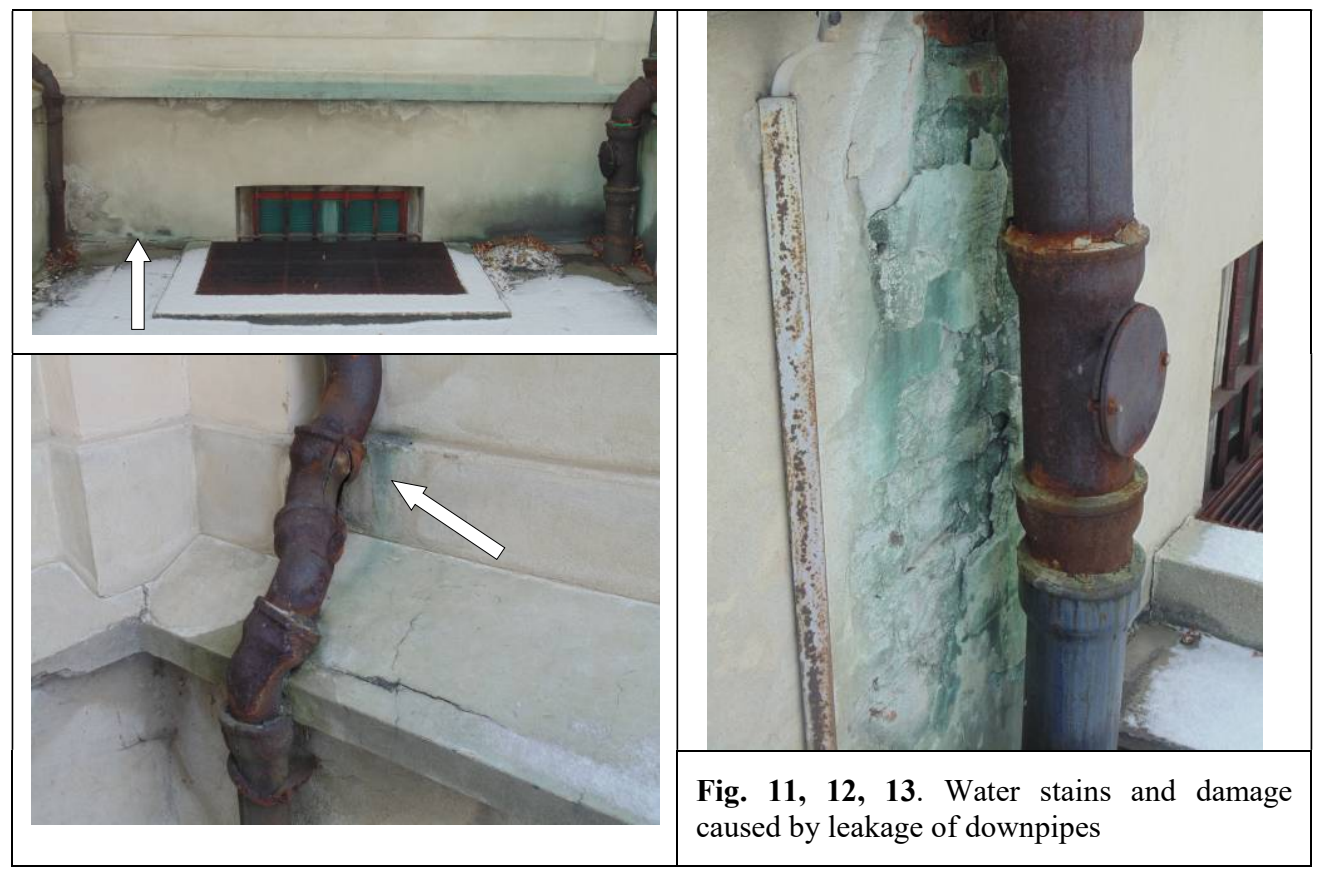

External basements were also insulated. Due to the poor technical condition of walls and vaults of these basements, insulation works were preceded by the execution of the casing in the form of an outer cladding (reinforced concrete walls and floors) (Fig. 14, 15). 
The purpose of this housing (dilatated from vaults and walls) is to transfer external loads from the internal road and car park located above the basement.

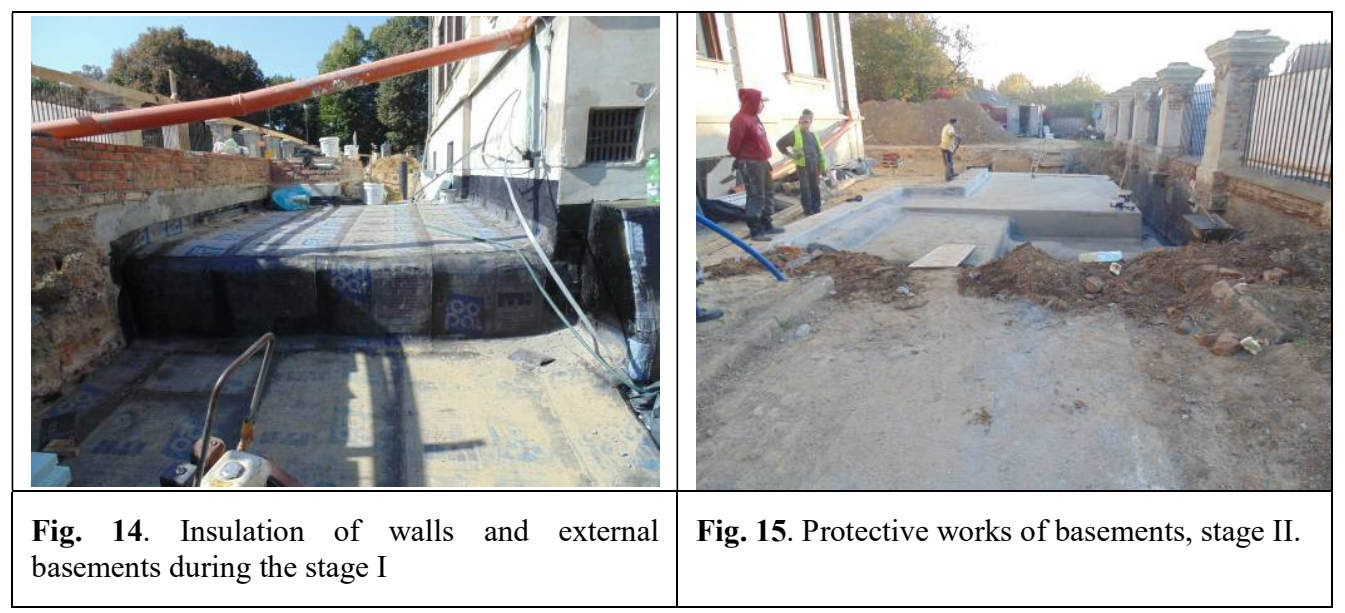

At the same time, internal work was carried out throughout the building. Plaster was removed from all walls except the corridors, where existing plasters were left. New installations were made. All floor layers have been removed. The floor was strengthened in the areas of the planned archive. The losses of weakened walls (Fig. 16) were supplemented by folding. Floor underlays were made. The housing of most walls was made of gypsum plasterboards. The existing plasters were left only on the walls of the corridors. Due to the need to remove the salinity and moisture from the basement walls, after they have been mouldered, the Ceresit system renovation plasters were made there. The window carpentry was replaced and the existing door was restored. In the additional openings new one was made, based on the existing model. New window sills have been installed. In the representative rooms modern stucco was added. New floors have been made. They were adapted to the character of the rooms. In the basements with the entrance from the fountain to the level of "-1", of natural wild sandstone from Komańcza. On the level of "-1" floor was made of impregnated ceramic tiles with a raw brick structure. Marble floors in all rooms on the ground floor, and only on corridors and toilets on the next floors and carpet flooring in other rooms. The stairs finished lastrico from the ground floor to the higher floors were left in the existing state. Only the balustrade and railing have been restored. The basement stairs are lined with stone, it is a regular, flamed sandstone from Komańcza.

No original elements of the building interior have survived. No attempts were made to restore them after a fire in 1906 . Historical elements from a later period hardly survived due to the manner of use. The few remaining are:

- polychrome above the main entrance to the building described in conservator's documentation [7] (Fig. 16, 17).

- tiled stove on the ground floor in the south-western part (Fig. 18, 19),

They have been reconstructed and renovated by conservators of art works.

The polychrome was quite well preserved. It was gently cleaned with pulp of bread. The existing painting layer is protected with a solution of poly-alcohol. Next, the mineral paints based on poly-alcohol were applied. Way of applying paints - by scoring (in order to obtain the effect of vibration).

There were quite a few small cavities on the furnace surface. The cavities were supplemented with cerami mass with the reconstruction of the tile sculpture. One tile was replaced with a new, burnt-out one with faithful representation of the damaged tile pattern. The door has also been replaced. The whole surface of the tiles was painted with shiny ceramic paint. Way of applying paints - as above. 


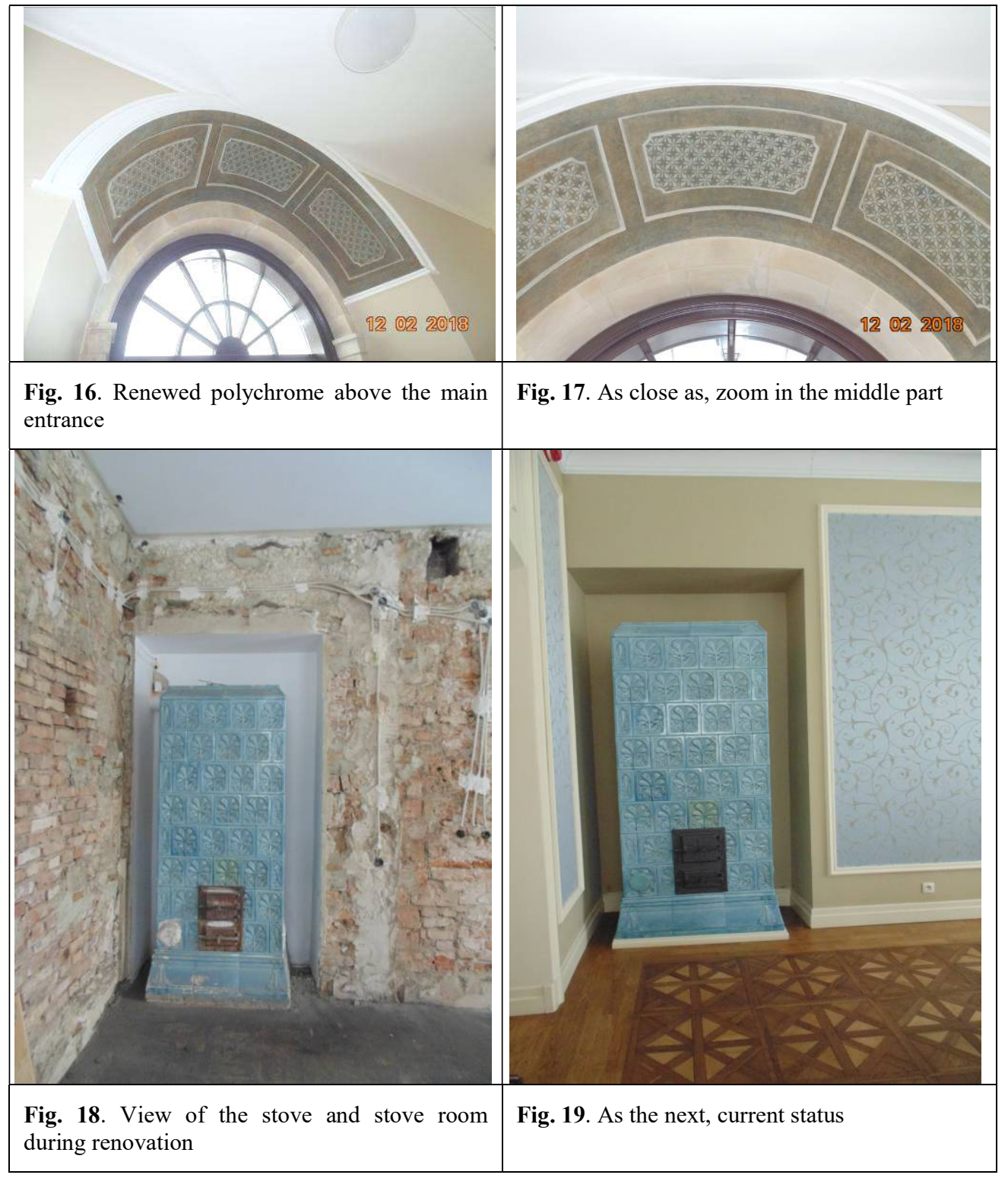

The stove room (this is how it was called after renovation) is the one of two rooms where the historic dance floor has been reconstructed. It is a parquet made of various types of wood, with an interesting geometric pattern (Fig. 17, 20 ). The second room is the office of the head of the Chamber, however, due to the type and pattern of floorboards (one color, one type of wood), no such an interesting visual effect has been obtained (Fig. 25).

Busts and lawns carved in stone - mostly by craftsmen during the previous renovation (based on historical patterns) have been cleaned, reconstructed and preserved if necessary. They are now an ornament of the hall, façade and fencing. In some of the cellar rooms exposed are raw, original fragments of walls. Below are photos of selected interiors after renovation (Fig. 20-33). 


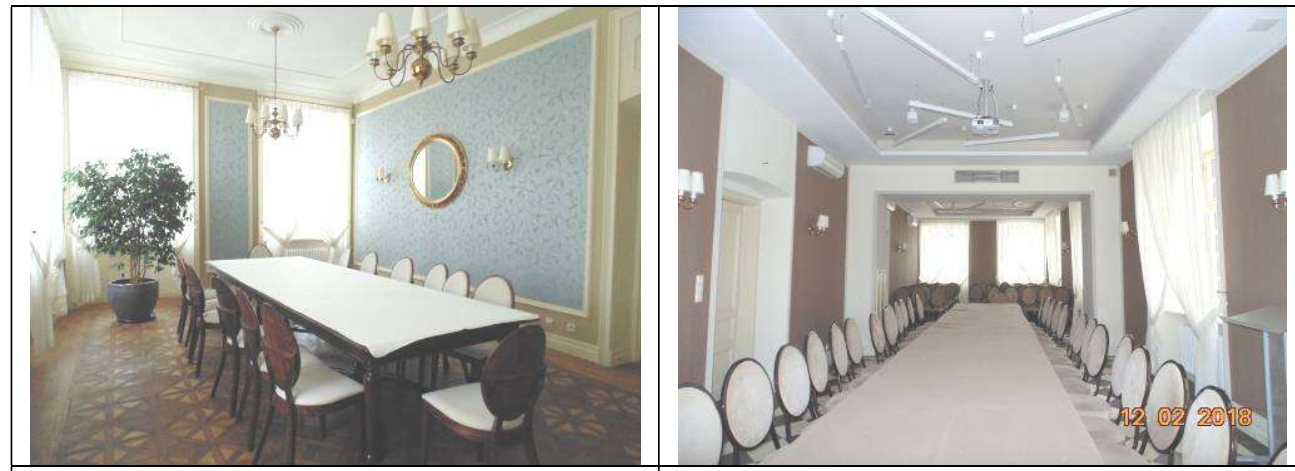

Fig. 20. Ground floor - stove room - view on the

Fig. 21. Conference room on the ground floor external eastern wall

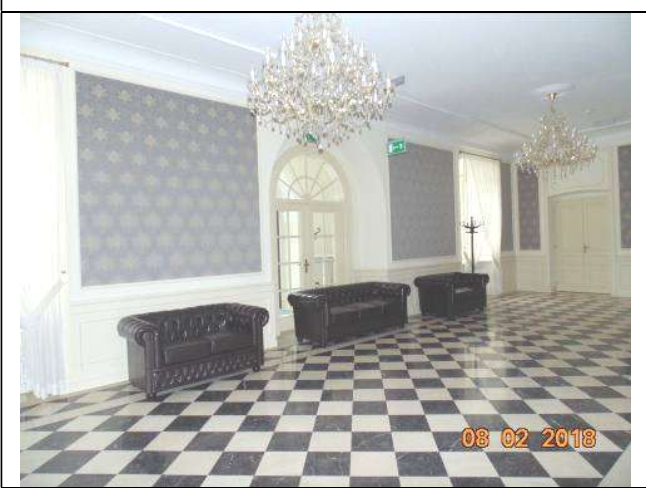

Fig 22. Hall on the ground floor

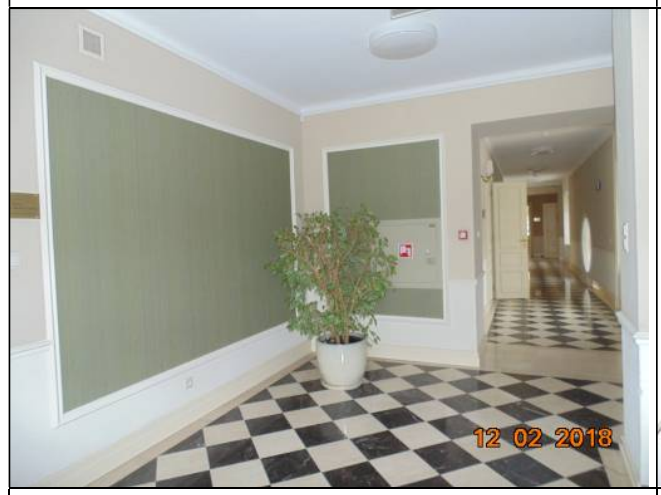

Fig. 24. Corridor on the second floor

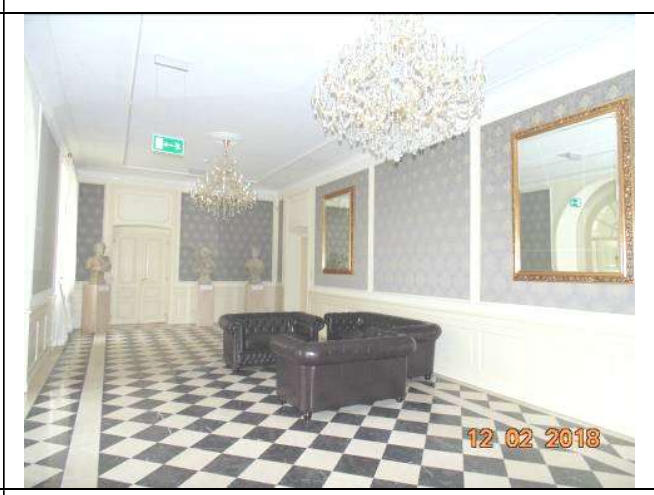

Fig 23. As the next - a different arrangement

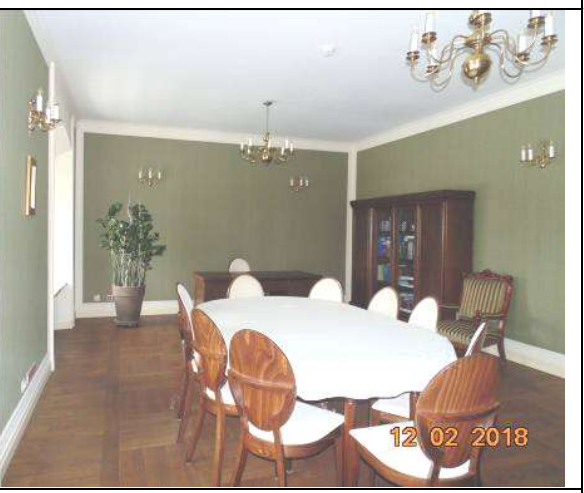

Fig. 25. Cabinet of the head of the Chamber 


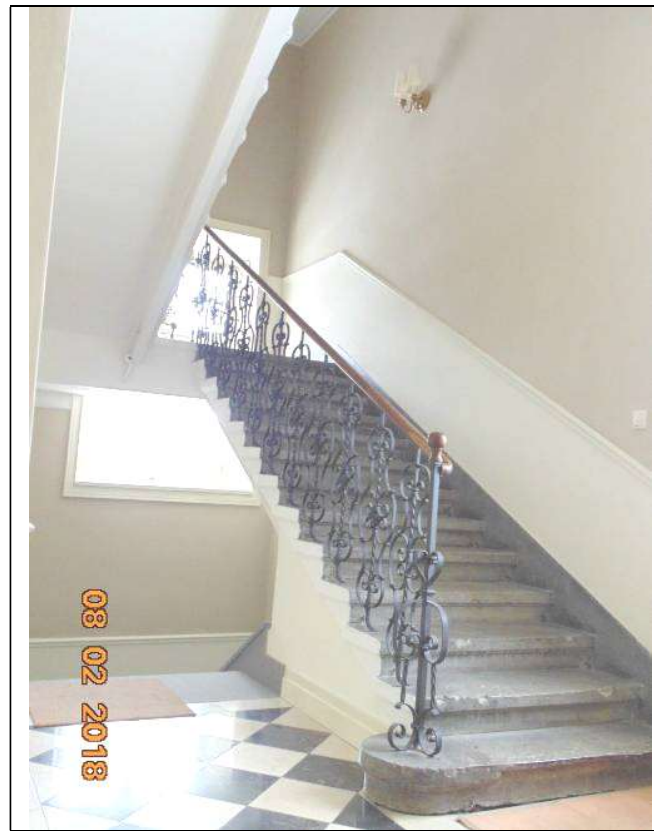

Fig. 26. Stairs from the ground floor to the first floor left without renovation

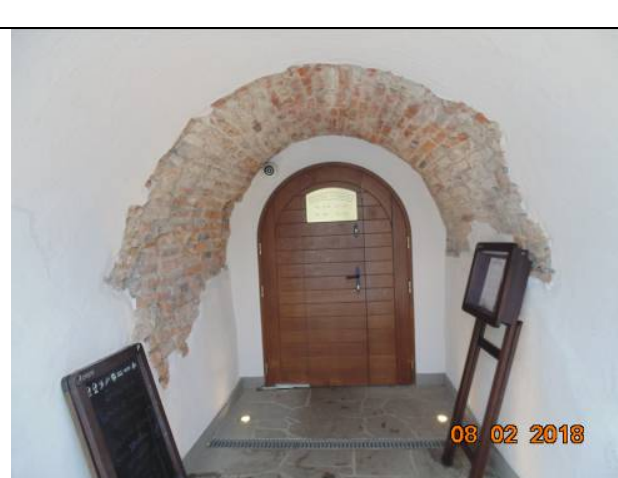

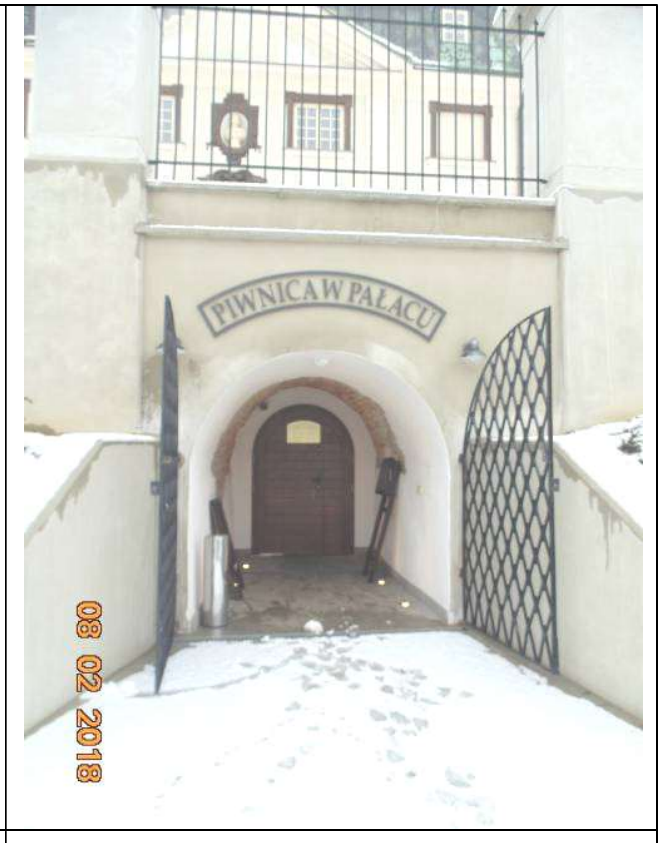

Fig. 27. The entrance to the basements from the fountain

Fig.28., 29. Corridor - basements, level "-2" 


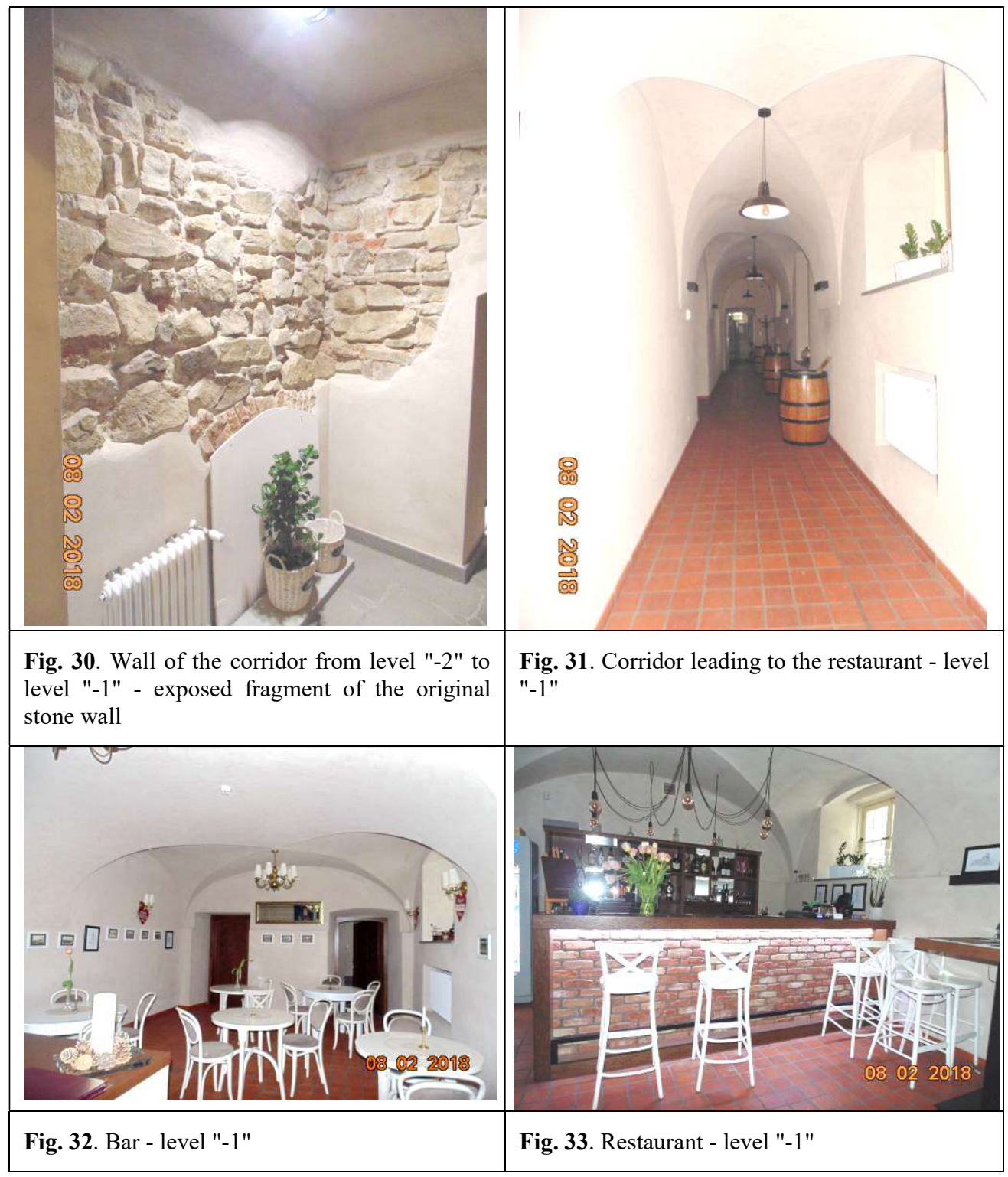

\section{Summary}

In order to bring the building to the correct condition it was necessary to perform a very wide range of construction works, which were necessary due to:

- faulty execution of works during the renovation carried out in the 80's of the last century,

- the need to remove negligence of the object's users from the period of 1982-2012,

- the normal technical wear of the facility.

The current appearance and character of the Palace is also the realization of the idea of the owner of the object. This idea consists in referring to the glory times of the Lubomirski Summer Palace by finishing the representative part of the building (whole ground and part of basements, the 2nd and 3rd floors) in a high standard of use. This goal has been 
undoubtedly achieved. It required the involvement of specialists in the field of construction and preservation of monuments and the workload of many people.

The contractor performing the entire investment task is AJ Profibud Company from Chmielnik near Rzeszów. The quality of the construction works of this company has been highly appreciated both by the owner of the facility and the authors of this article, who act as investor's supervisors over the implementation of the works.

Implementation of the project was also possible thanks to the efforts of the site owner and obtaining target subsidies from the President of the Rzeszów City and the Provincial Office for Monuments Protection in Przemyśl. The Regional Medical Chamber also incurred significant financial outlays from its own resources.

\section{References}

1. F. Kotula, Tamten Rzeszów, Wydawnictwo Libri Ressovienses, Rzeszów 1997.

2. http://www.rzeszow.pl/miasto-rzeszow/historia/zabytki-rzeszowa/palac-letnilubomirskich \{access 01.02.2018 r.\}.

3. The Monument Records card of the historic building "The Lubomirski Summer Palace Complex" No. 1329, has been completed 31.VIII.1959 r. by T. Zurawska. In 1968, the registration number was changed to A-292.

4. S. Hałabuz: "Construction and executive design for the reconstruction, renovation and change of the way of using the building of the Lubomirski Summer Palace for an administrative building with catering and guest rooms for the needs of the District Medical Chamber in Rzeszów ... ", Rzeszów, October 2013.

5. K. Wróbel, W. Kubiszyn, Repairs of historical fence of the Summer Lubomirski Palace in Rzeszow, Journal of Civil Engineering, Environment and Architecture, JCEEA, t. XXXIII, z. 63 (3/16), June-July 2016, s. 101-108.

6. Wróbel K., Restoration of the façades of the Summer Lubomirski's Palace in Rzeszow, Journal of Civil Engineering, Environment and Architecture, JCEEA, t. XXXIV, z. 64 (3/II/17), Rzeszów 2017, s. 443-453.

7. Orysiak R., Conservator's documentation of the polychromy in the arch above the entrance to the Lubomirski Palace in Rzeszów, the Laboratory of Conservation of Monuments, Rzeszów Branch, Laboratory of Conservation of Works of Art in Rzeszów, Rzeszów 1989. 